Assessment of Effectiveness of

Geologic Isolation Systems

\title{
Identifying Suitable "Piercement" Salt Domes for Nuclear Waste Storage Sites
}

R. Kehle

Turk, Kehle and Associates

August 1980

Prepared for the

Office of Nuclear Waste Isolation

under its Contract with the

U.S. Department of Energy

Pacific Northwest Laboratory

Operated for the U.S. Department of Energy

by Battelle Memorial Institute 
This report was prepared as an account of work sponsored by the United States Government. Neither the United States nor the Department of Energy, nor any of their employees, nor any of their contractors, subcontractors, or their employees, makes any warranty, express or implied, or assumes any legal liability or responsibility for the accuracy completeness or usefulness of any information, apparatus, product or process disclosed, or represents that its use would not infringe privately owned rights.

The views, opinions and conclusions contained in this report are those of the contractor and do not necessarily represent those of the United States Government or the United States Department of Energy.

\author{
PACIFIC NORTHWEST LABORATORY \\ operated by \\ BATTELLE \\ for the \\ UNITED STATES DEPARTMENT OF ENERGY \\ Under Contract DE-AC06-76RLO 1830
}

\author{
Printed in the United States of America \\ Available from \\ National Technical Information Service \\ United States Department of Commerce \\ 5285 Port Royal Road \\ Springfield, Virginia 22151
}

Price: Printed Copy $\$$

$\because$ Microfiche $\$ 3.00$

NTIS

-Pages Selling Price

$\begin{array}{ll}001-025 & \$ 4.00 \\ 026-050 & \$ 4.50 \\ 051-075 & \$ 5.25 \\ 076-100 & \$ 6.00 \\ 101-125 & \$ 6.50 \\ 126-150 & \$ 7.25 \\ 151-175 & \$ 8.00 \\ 176-200 & \$ 9.00 \\ 201-225 & \$ 9.25 \\ 226-250 & \$ 9.50 \\ 251-275 & \$ 10.75 \\ 276-300 & \$ 11.00\end{array}$

4 


\section{3}

Assessment of Effectiveness of Geologic Isolation Systems

IDENTIFYING SUITABLE "PIERCEMENT" SALT DOMES FOR NUCLEAR WASTE STORAGE SITES

R. Kehle

Turk, Kehle and Associates

August 1980

Prepared for the Office of Nuclear Waste Isolation under its Contract with the U.S. Department of Energy

Pacific Northwest Laboratory Richland, Washington 99352 



\section{PREFACE}

Associated with commercial nuclear power production in the United States is the generation of potentially hazardous radioactive waste products. The Department of Energy (DOE), through the National Waste Terminal Storage (NWTS) Program and the Office of Nuclear Waste Isolation (ONWI), is seeking to develop nuclear waste isolation systems in geologic formations. These underground waste isolation systems will preclude contact with the biosphere of waste radionuclides in concentrations which are sufficient to cause deleterious impact on humans or their environments. Comprehensive analyses of specific isolation systems are needed to assess the post-closure expectations of the systems. The Assessment of Effectiveness of Geologic Isolation Systems (AEGIS) Program has been established for developing the capability of making those analyses.

Among the analyses required for the system evaluation is the detailed assessment of the post-closure performance of nuclear waste repositories in geologic formations. This assessment is concerned with aspects of the nuclear program which previously have not been addressed. The nature of the isolation systems (e.g., involving breach scenarios and transport through the geosphere) and the great length of time for which the wastes must be controlled dictate the development, demonstration, and application of novel assessment capabilities. The assessment methodology must be thorough, flexible, objective, and scientifically defensible. Furthermore, the data utilized must be accurate, documented, reproducible, and based on sound scientific principles.

The current scope of AEGIS is limited to long-term, post-closure analyses. It excluses the consideration of processes that are induced by the presence of the wastes, and it excludes the consideration of nuclear waste isolation in media other than geologic formations. The near-field/near-term aspects of geologic repositories are being considered by ONWI/DOE under separate programs. They will be integrated with the AEGIS methodology for the actual site-specific repository safety analyses. 
The assessment of repository post-closure safety has two basic components:

- identification and analyses of breach scenarios and the pattern of events and processes causing each breach;

- identification and analyses of the environmental consequences of radionuclide transport and interactions subsequent to a repository breach.

The Release Scenario task of AEGIS is charged with identifying and analyzing breach scenarios and their associated patterns of events and processes.

The Release Scenario task is concerned with evaluating the geologic system surrounding an underground repository and describing the phenomena which alone or in concert could perturb the system and possibly cause a loss of repository integrity. Output from the Release Scenario task will establish the boundary conditions of the geology and hydrology surrounding the repository at the time of an identified breach. These bounding conditions will be used as input for the consequence analysis task, which will employ sophisticated hydrological transport models to evaluate the movement of radionuclides through the groundwater system to the biosphere.

AEGIS has contracted with a number of consultants to obtain expert scientific opinion about the geologic processes which could affect an underground repository. The consultants were asked to specify processes and events which might affect potential repository sites and, if possible, to give rates and probabilities for those phenomena. The consultants have also been involved with the description of the system interactions and synergisms.

This report contains information obtained by one of the AEGIS consultants during the FY-1978 research effort. The research described in this document is being continued during FY-1979 and FY-1980. Because of the ongoing nature of the Release Scenario methodology development effort, many of the results and conclusions outlined in this report are subject to change upon completion of additional research and analyses. The information contained in this report is based upon the expert opinion of an individual consultant and should be treated as such. 


\section{CONTENTS}

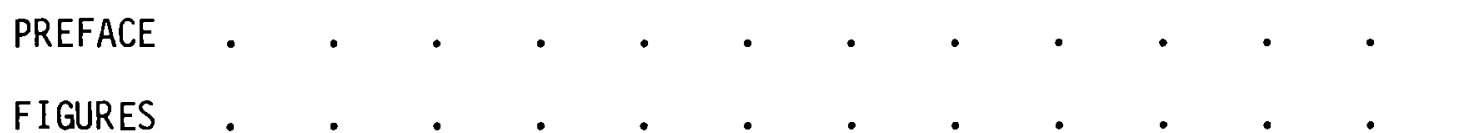

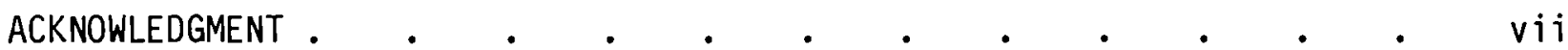

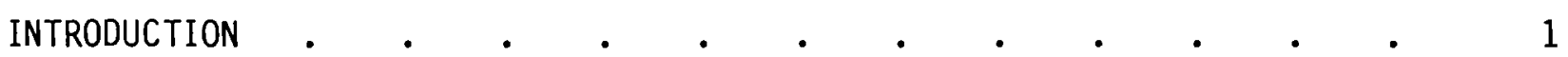

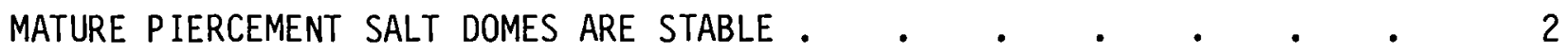

SEDIMENT LOADING CAUSES DOME GROWTH $\quad$ • • • • • • $\quad 2$

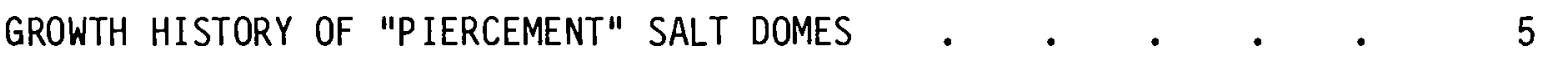

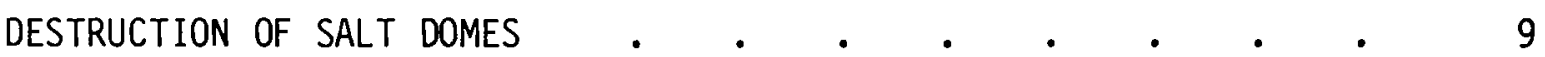

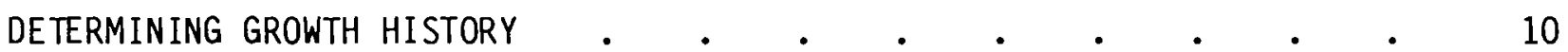

CDP PROFILE QUALITY •

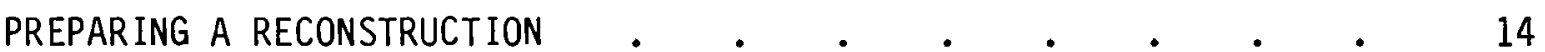

AN EXAMPLE OF RECONSTRUCTION

GEOLOGIC HAZARDS TO A SALT DOME STORAGE SITE . • • • • 22

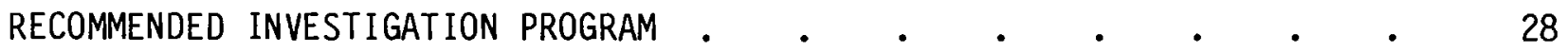

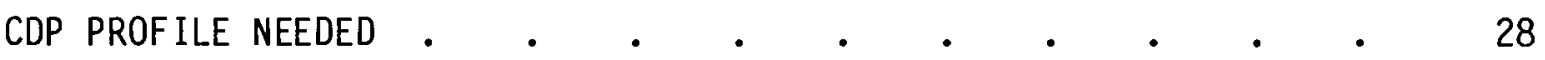

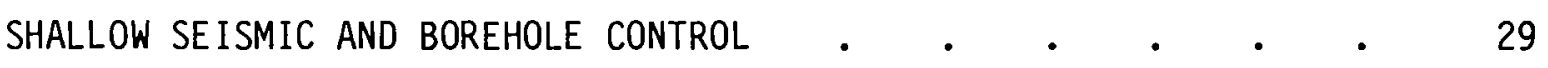

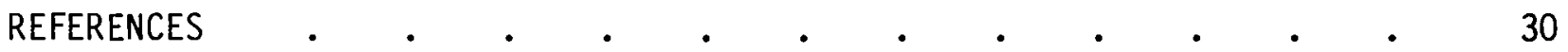




\section{FIGURES}

1 Differential Stress-Strain Curves for Polycrystalline Halite

Extended at $2 \mathrm{~kb},:-1.9 \times 10^{-2}$ to $1.2 \times 10^{-7} \mathrm{sec} .-1 . .4$

2 Diagramatic Development of a Salt Dome in the Northern Germany

3a Interpreted Configuration of the Hainesville Dome at the End of Fredricksburg Deposition (upper diagram) and Woodbine Deposition (lower diagram)

3b Interpreted Configuration of the Hainesville Dome at the End of Taylor Deposition (upper diagram) and Navarro Deposition (lower diagram) .

4 Exxon 12 Fold CDP Seismic Profile, Trending NE-SW Across the Hainesville Salt Dome, Wood County, Texas . • . . $\quad$ • 11

5 Model of Migrated Seismic Profile (Figure 4) in Depth-Output 3

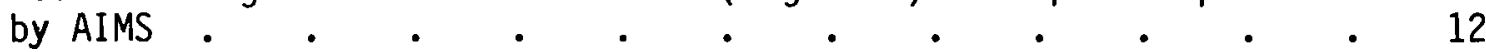

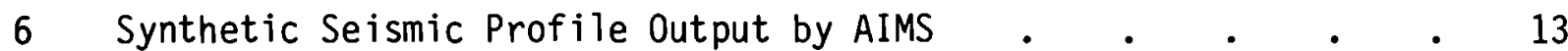

7 Depth Model Used in Reconstructing Growth History of the Hainesville Salt Dome, Wood County, Texas . . . . . 16

8a Reconstruction - Datum Top Cotton Valley Limestone _ . • 17

8b Reconstruction - Datum Top Travis Peak . . . . . . . 17

8c Reconstruction - Datum First Anhydride Stringer . . . . 17

9a Reconstruction - Datum Top Paluxy . . . . . . . . . 19

9b Reconstruction - Datum Top Comanchean . . . . . . . . 19

10a Reconstruction - Datum Top Lower Eagle Ford . . . . . 20

10b Reconstruction - Datum Base Austin Chalk . . . . . 20

11a Reconstruction - Datum Top Pecan Gap Chalk • . . $\quad$ • 21

11b Reconstruction - Datum Top Navarro Mar 1. . . . . . . 21

12 Structural Relief - Hainesville Salt Dome . $\quad$ • . . . 24

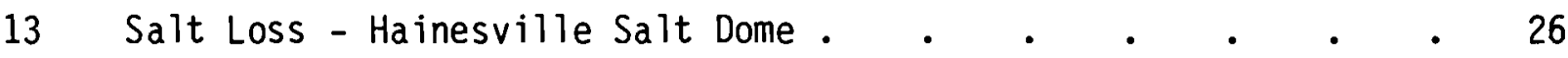




\section{ACKNOWLEDGEMENT}

Th is research was supported by the Waste Isolation Safety Assessment Program (WISAP) conducted by Pacific Northwest Laboratory. The program was sponsored by the Office of Nuclear Waste Isolation, managed by Battelle Memorial Institute for the Department of Energy under Contract DE-AC06-76RL0-1830. On 1 October 1979, WISAP became the Assessment of Effectiveness of Geologic Isolation Systems (AEGIS) Program and the Waste/Rock Interactions Technology (WRIT) Program. This report was issued by AEGIS. 



\section{INTRODUCTION}

"Piercement" salt domes of the northern interior salt basins of the Gulf of Mexico are being considered as permanent storage sites for both nuclear and chemically toxic wastes. The suitable domes are stable and inactive, having reached their final evolutionary configuration at least $30 \mathrm{million}$ years ago. They are buried to depths far below the level to which erosion will penetrate during the prescribed storage period and are not subject to possible future reactivation. The salt cores of these domes are themselves impermeable, permitting neither the entry nor exit of ground water or other unwanted materials.

In part, a stable dome may be recognized by its present geometric configuration, but conclusive proof depends on establishing its evolutionary state. The evolutionary state of a dome is obtained by reconstructing the growth history of the dome as revealed by the configuration of sedimentary strata in a large area (commonly 3,000 square miles or more) surrounding the dome. A high quality, multifold CDP reflection seismic profile across a candidate dome will provide much of the necessary information when integrated with available subsurface control. Additional seismic profiles may be required to confirm an apparent configuration of the surrounding strata and an interpreted evolutionary history. High frequency seismic data collected in the near vicinity of a dome are also needed as a supplement to the CDP data to permit accurate depiction of the configuration of shallow strata. Such data must be tied to shallow drill hole control to confirm the geologic age at which dome growth ceased. If it is determined that a dome reached a terminal configuration many millions of years ago, such a dome is incapable of reactiviation and thus constitutes a stable storage site for nuclear wastes. 


\section{MATURE PIERCEMENT SALT DOMES ARE STABLE}

"Piercement" salt domes of the northern interior salt basins of the Gulf of Mexico do not form as a result of a mass of salt rising buoyantly upwards through an overlying sequence of sedimentary strata. Rather, such domes are salt pillars extruded through an erosional hole in the sedimentary cover of a concordant salt structure. The most common predecessors to "piercement" domes are salt "pillows". The extrusion is caused by active sediment loading of the predecessor salt structure, as is the initiation of growth of the original structure. Consequently, "piercement" domes follow a predictable evolutionary sequence which terminates in a mature, stable configuration. A stable configuration is characterized by: 1) complete evacuation of salt from the original salt structure, 2) steep or overhanging dome flanks, and 3) the existence of a continuous sedimentary stratum, preferably Pliocene or older, across the crest of the feature. Once a dome reaches this stable configuration, growth ceases, regardless of whether or not the dome is buried beneath an increasing cover of

sediments. Even if the dome is unroofed by erosion, no further salt extrusion occurs. Solution collapse is more likely in such circumstances. Destruction of an existing dome occurs only through erosion and solution by ground water flow. Both of these processes are slow compared to the storage time requirements of nuclear wastes.

\section{SEDIMENT LOADING CAUSES DOME GROWTH}

Both analytic studies (Kehle 1971) and geologic investigations (Fisher 1973) indicate that sediment loading, not buoyancy, sensu stricto, is responsible for the growth of salt domes. Ideally, buoyancy might cause salt domes to form, because the occurrence of a denser fluid over a less dense fluid is inherently unstable. But the forces within a salt mass resulting from such a density inversion are always far less than those resulting from uneven sediment loading. This difference is highly magnified in the resulting salt flow, because the apparent viscosity of salt is very sensitive to shear stress. In 
fact, the deformation resulting from uneven sediment loading proceeds so rapidly that buoyancy effects are not discernible. The following analysis illustrates this conclusion.

A gravity or buoyancy instability depends on the existence of both a density inversion and either an imperfection in the contact surface between the two materials or a non-horizontal contact surface. The hydraulic gradient within a buried salt mass resulting from buoyancy forces is proportional to the density contrast between salt and the overlying sediment and to the local slope of the contact surface. Compaction curves for most sediments show that densities of $2.2 \mathrm{~g} / \mathrm{cm}^{3}$ (the density of salt) occur only at burial depths of 3,000 to 4,000 feet or more, depending on sediment type. Thus, buoyancy comes into play only at substantial burial depths. The maximum density contrast expected is for a mixed limestone-anhydrite sequence, where average in situ densities may equal $2.75 \mathrm{~g} / \mathrm{cm}^{3}$.

In comparison, the hydraulic gradient within a salt mass resulting from uneven sediment loading depends on the slope of the sediment anomaly and the density contrast between sediment and sea water. The slope of the sediment anomaly is the height divided by the width of a delta lobe or similar subsea feature. The topographic anomalies associated with uneven sedimentation are demonstrably equal to or greater than the expected anomalies in salt sediment interfaces. Thus, the advantage, however slight, lies with uneven sedimentation. The principal difference is with the density contrast, because even with an undercompacted muddy delta lobe, the density contrast equals $0.9 \mathrm{~g} / \mathrm{cm}^{3}$ or more. This minimum contrast is $80 \% 1$ arger than the maximum contrast anticipated between sediment and salt (most sediment-salt density contrasts are much lower) and thus the resulting hydraulic gradients will be equally larger.

The effect of the above differences in anticipated hydraulic gradient is much amplified in the development of salt structures because of the mechanical characteristics of halite. Constant strain-rate experiments (Heard 1976) show that the majority of 1 arge, permanent deformation in salt is accomplished through steady-state creep (Figure 1). The rate of creep is very sensitive to 


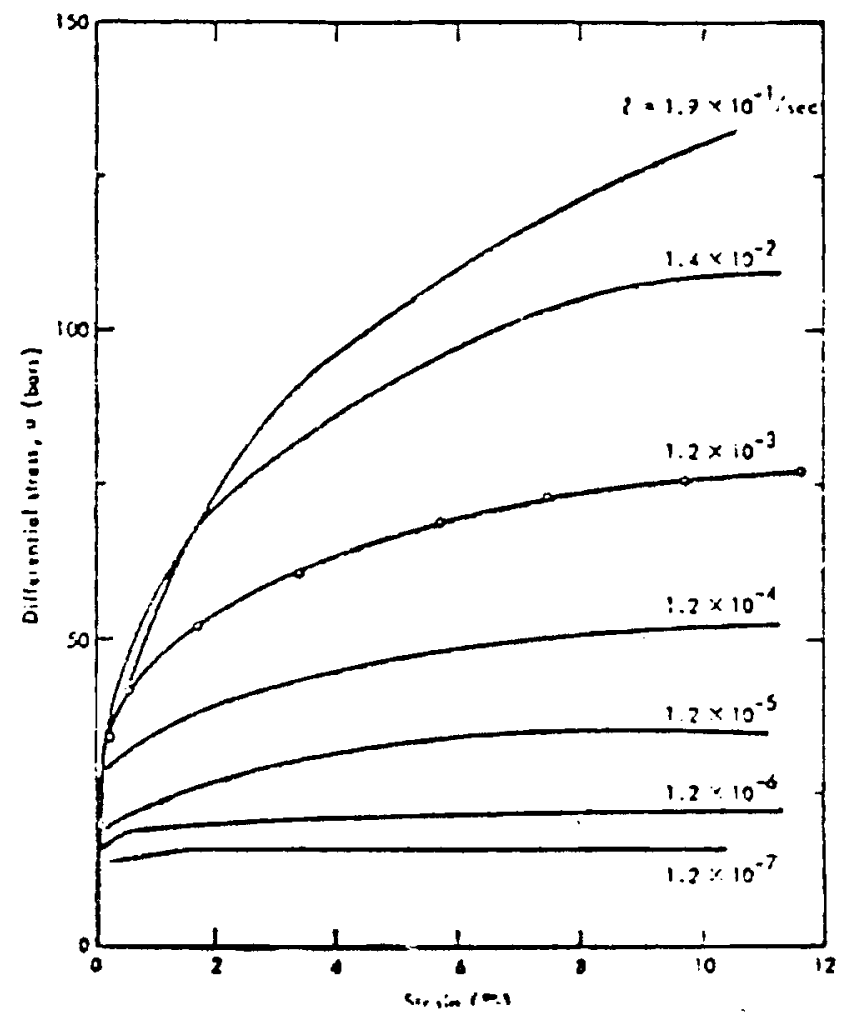

FIGURE 1. Differential Stress-Strain Curves for Polycrystalline Halite Extended at $2 \mathrm{~kb},-1.9 \times 10^{-2}$ to $1.2 \times 10^{-7} \mathrm{sec} .-1$

(from Heard 1976)

the magnitude of the differential stress (the hydraulic gradient). Figure 1 shows that an order of magnitude change in strain rate results in nearly $15 \%$ difference in stress. The minimum difference in hydraulic gradient between buoyancy and sediment loading, i.e., $80 \%$, translates into more than four orders of magnitude difference in strain-rate. Under these circumstances the contribution of buoyancy to total deformation is negligible.

The above conclusion is supported by geologic evidence. Fisher (1973) found that salt dome growth in the Gulf of Mexico region correlates with episodes of major deltaic progradation into the area. Growth of domes in the northern interior basins can also be correlated with delta progradation. Growth of these domes began during the influx of Late Jurassic Cotton Valley and Early Cretaceous Travis Peak and Tuscaloosa deltas (Loocke 1978). 
GROWTH HISTORY OF "PIERCEMENT" SALT DOMES

All interior domes that have been studied exhibit the same stages in their development. These are: 1) initiation, 2) salt pillow formation, 3) truncation, 4) extrusion and collapse, and 5) burial. This evolutionary history was first recognized by Trusheim (1960) and Sannemann (1968). These writers failed to recognize that the salt core of a pillow (stage 2) was exposed sub-aerially as a result of erosional truncation (stage 3 ) before the extrusion of the salt pillar (stage 4). This fact was first recognized by Kehle (1971) and later confirmed by Loocke (1978).

Trushe im (1960) schematically sumarized this evolutionary growth sequence (Figure 2). Figures $3 \mathrm{a}$ and $3 \mathrm{~b}$ show a reconstruction for the Hainesville Dome, Wood County, Texas, by Kehle (1971). The extrusion phase is especially significant. During this period, the salt leaves its proper stratigraphic position (previously the structure was concordant) and passes through an eroded hole in the capping sediments. If sedimentation occurs simultaneously, the new deposits onlap the growing salt pillar. Not surprisingly, much salt is lost during this stage of the dome's development. Loocke (1978) calculated that of 45 cubic miles of salt in the initial salt pillow at Hainesville, only 9 cubic miles presently remain in the pillar. The remainder was lost through erosion and dissolution. Thus, during the extrusion phase, salt does move upward past the newly deposited onlapping sediments. This process deforms the immediately adjacent sediments and destroys the original sedimentary contacts. The geometry of the contact is also changed during this phase. The sediments collapse into the void created through evacuation of the original salt pillow.

The final stage of the evolution of a dome occurs as the last volumes of salt are extruded from the underlying salt pillow. During this time, sediments commonly bury the dome, and subsequent growth is insufficient to raise the new sediments above the base level of erosion. Instead, these latest sediments are only arched over the salt pillar. If further sedimentation occurs, these strata will extend undeformed across the structure, indicating that all growth has ceased. 

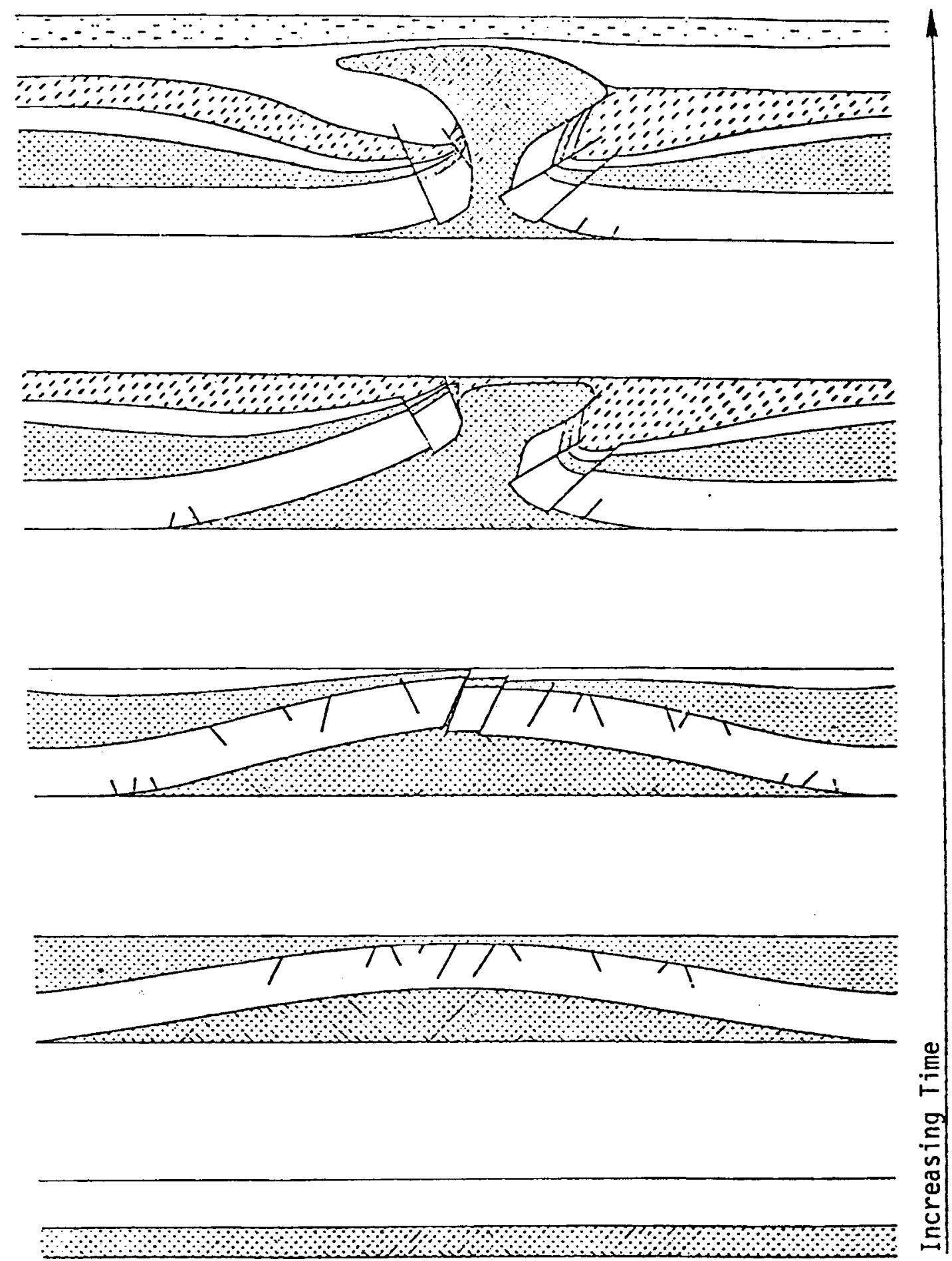

FIGURE 2. Diagrammatic Development of a Salt Dome in the North Germany Salt Basin (from Trusheim 1960). Sedimentary Column and Growth History is Similar to Domes in the Northern Interior Salt Basins of the Gulf of Mexico. 

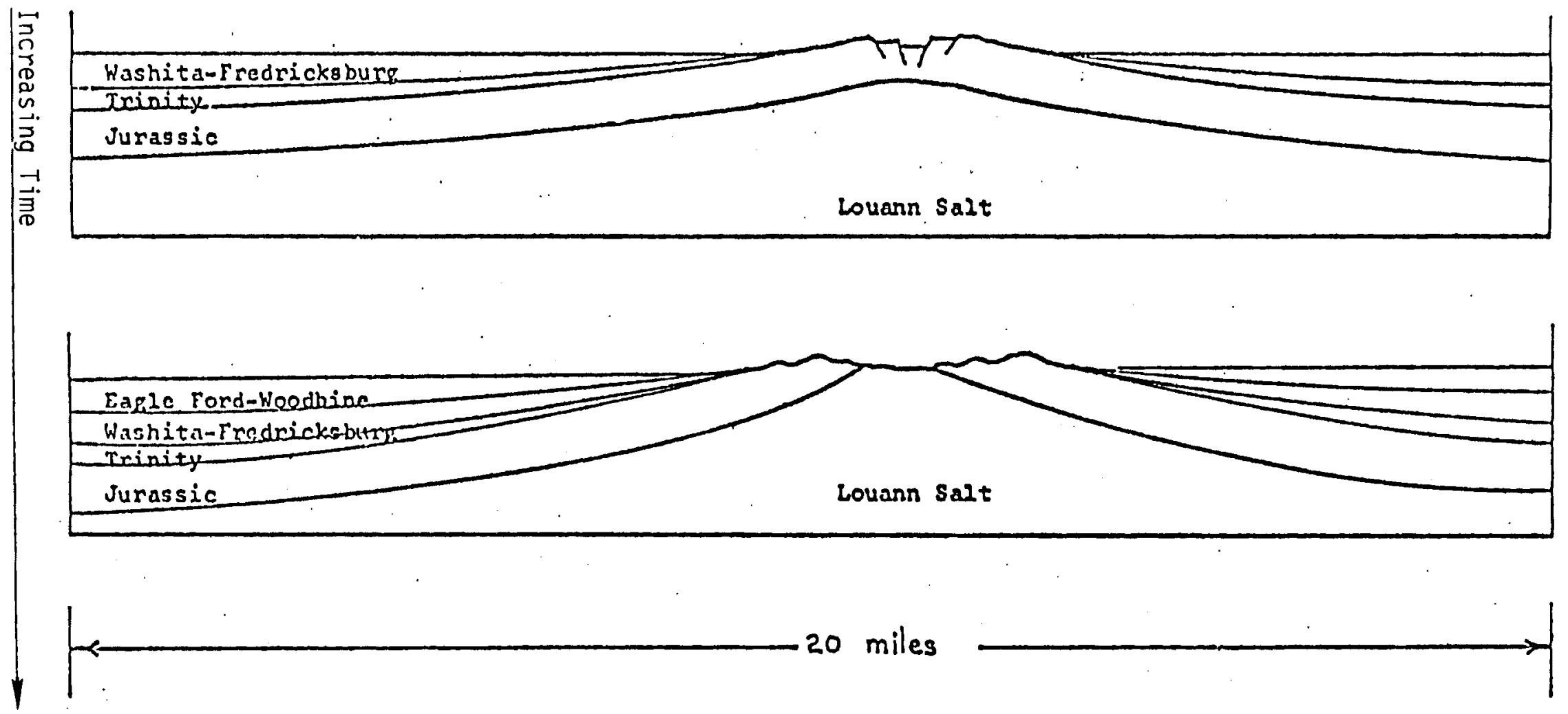

FIGURE 3a. Interpreted Configuration of the Hainesville Dome at the End of Fredricksburg Deposition (upper diagram) and Woodbine

Deposition (lower diagram). Reconstruction made Using Seismic

Time Section (from Kehle 1971). 


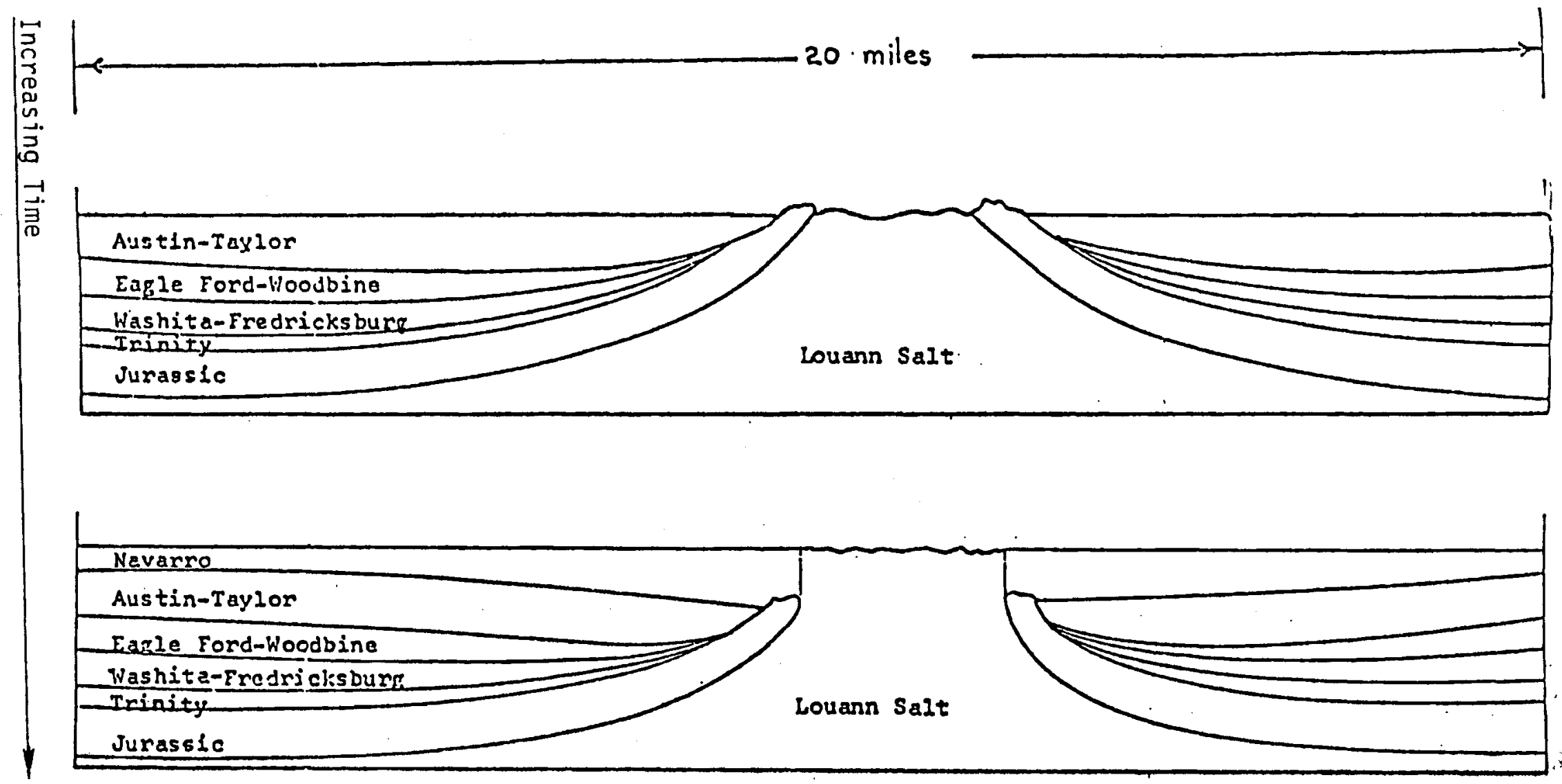

FIGURE 3b. Interpreted Configuration of the Hainesville Dome at the End of Taylor Deposition (upper diagram) and Navarro Deposition (lower diagram). Reconstruction Made Using Seismic Time Section (Figure 4) (from Kehle 1971). 
From this history it can be concluded that once the salt has been completely evacuated from the original salt pillow, growth of the piercement pillar ceases. In the interior basins of the northern Gulf of Mexico, most domes reached this evolutionary stage in the Late Cretaceous or early Tertiary. Because sedimentation also ceased at that time, undeformed capping sediments are rarely present across domes in this region. But sediments of considerable age ( 30 to 50 million years) remain intact across most of these structures, indicating that growth ceased at the latest in the early Tertiary.

\section{DESTRUCTION OF SALT DOMES}

As with any geologic feature, salt domes may be removed from the earth's crust through erosion. This process is usually too slow to be of significance to waste disposal problems; a great amount of time can be required to wear away rocks at the earth's surface. Of greater concern is the possibility of solution collapse of the salt spine. Solution of salt and subsequent collapse of the dome might occur if the crest of the spine became exposed because of future erosion. Percolation of ground water could also cause solution collapse. This type of salt dome destruction can be protected against by restricting disposal sites to those domes whose upper reaches are enveloped by impervious strata (preferably shale) and whose crests are sufficiently buried to preclude exposure during the prescribed storage period. 


\section{DETERMINING GROWTH HISTORY}

The growth history of an interior basin salt dome is revealed by high quality reflection seismic data, if interpretable data reach to the depth of the pre-salt surface. The seismic coverage must extend well beyond the primary withdrawal area - typically 15 to 20 miles from the center of the dome. Extensive coverage insures proper identification of the principal withdrawal sink. The growth history is reconstructed by preparing isochron profiles for a sequence of seismic stratigraphic units and superposing them sequentially. Migrated depth sections are best suited for the reconstruction process, although results derived from time sections yield similar results. Normal move-out velocities are inadequate for preparation of migration and depth sections. Unless more accurate interval velocities can be obtained, time sections should be used in reconstructions.

\section{CDP PROFILE QUALITY}

Figure 4 shows a CDP profile of adequate quality for reconstructing the growth history of an interior basin piercement dome. The profile clearly shows the pre-salt surface, and coverage extends well beyond the primary peripheral salt withdrawal area. The record possesses good reflection quality throughout most of the post-salt sedimentary sequence. A profile must have all of these characteristics to allow reconstruction of the growth history. The profile, obtained from Exxon Company, USA, crosses the Hainesville salt dome, Wood County, Texas, along a NE-SW line.

The pre-salt surface reflection is identified on Figure 4. Experience in the northern interior basins shows that this surface is always planar and easily identified. It is undeformed except in a few locales where it is offset along normal faults of early to middle Mesozoic age. The apparent disruption of the pre-salt surface beneath the dome results from the method of presentation -- horizontal distance versus reflection time. Because seismic energy travels faster through the salt dome than through the surrounding sediments, the pre-salt surface reflection occurs at less time below the dome 

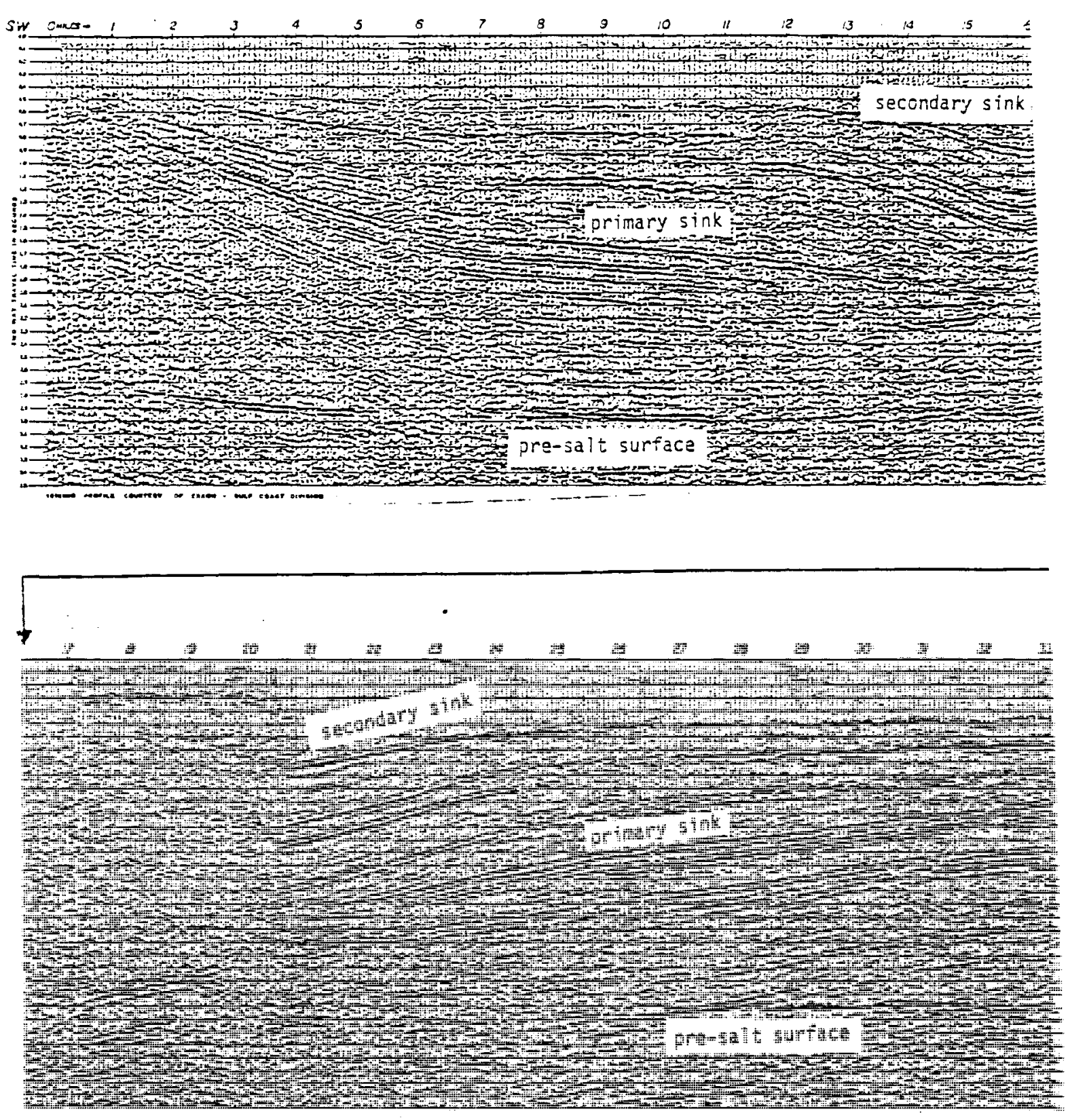

FIGURE 4. Exxon 12 Fold CDP Seismic Profile, Trending NE-SW Across the Hainesville Salt Dome, Wood County, Texas (from Loocke 1978)

than to either side. The validity of this explanation is confirmed by a computer simulation of the seismic section shown in Figure 4. A model interpretation of the depth section (Figure 5) is introduced into an AIMS program, which computes the seismic profile that would be obtained across such a geologic feature (Figure 6 ). Notice that the model has a continuous planar 


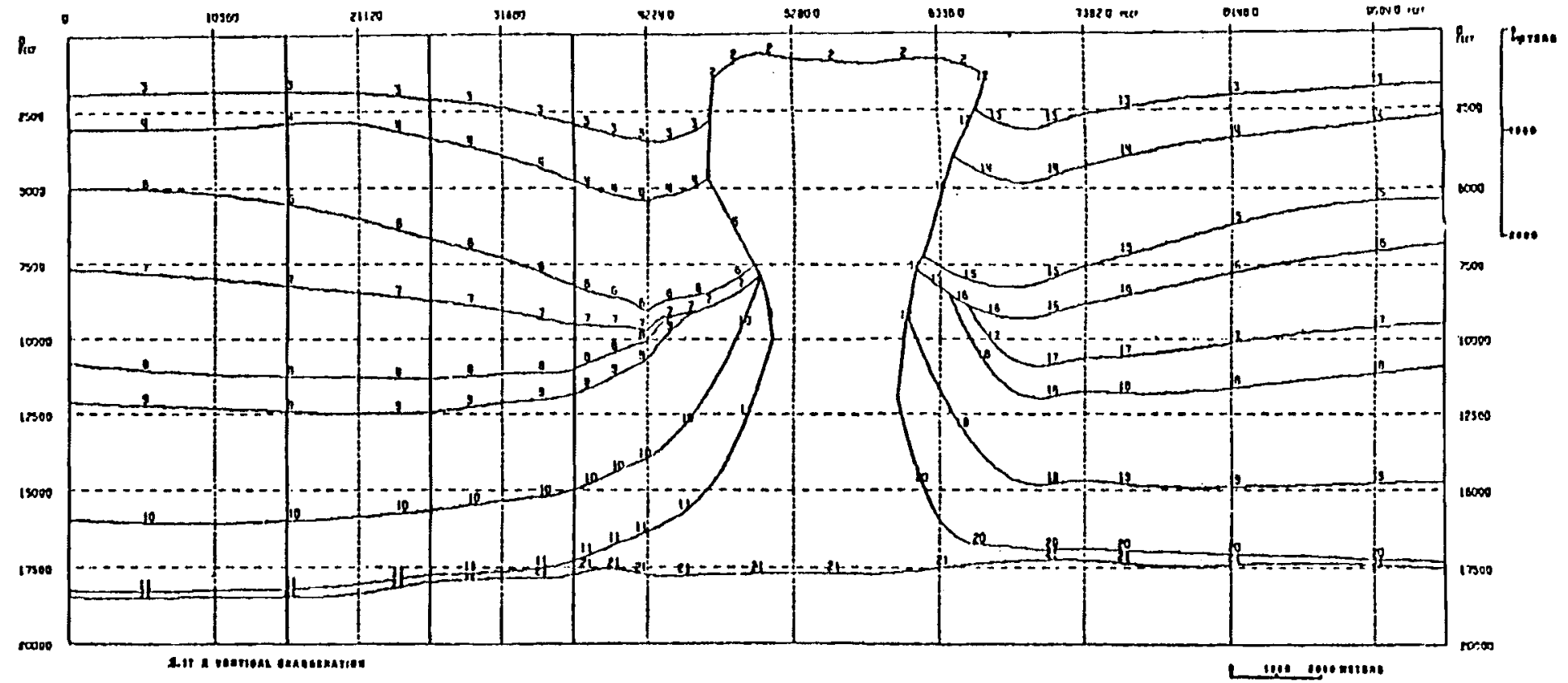

FIGURE 5. Model of Migrated Seismic Profile (Figure 4) in Depth-Output by AIMS (from Loocke 1978) 


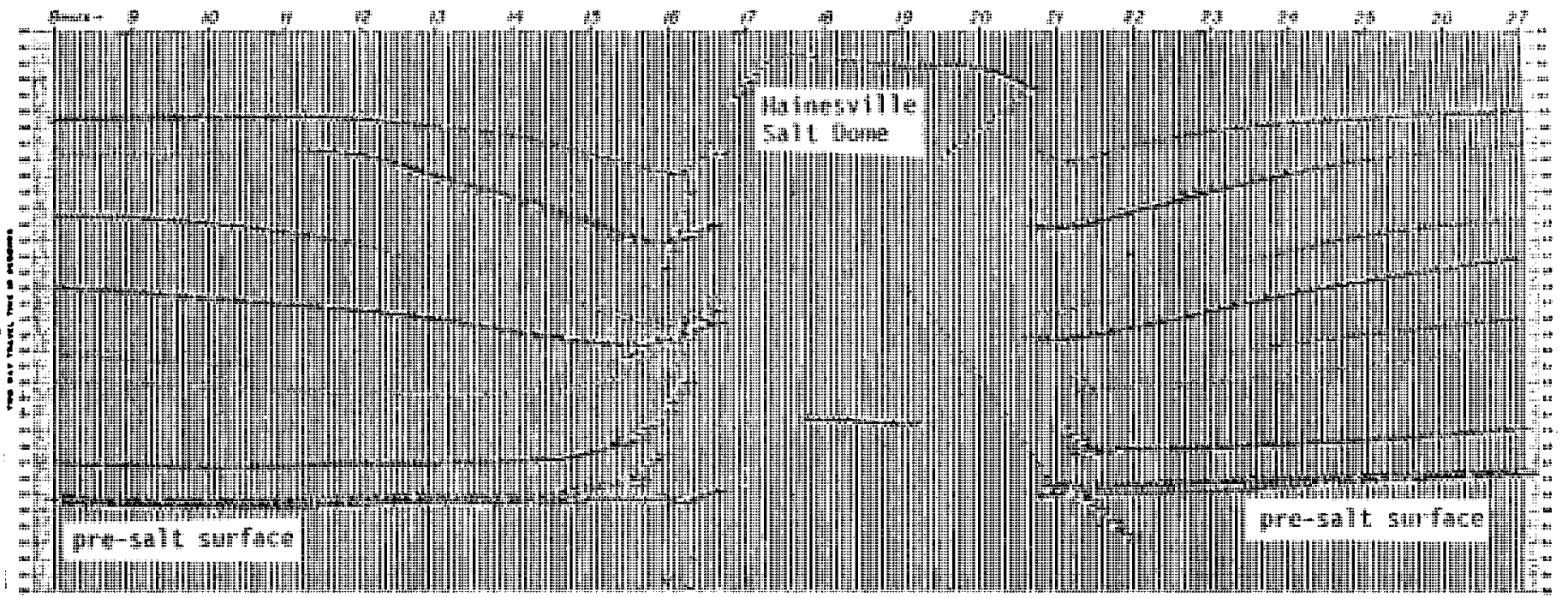

FIGURE 6. Synthetic Seismic Profile Output by AIMS. Compare with Figure 4. Note Elevated Pre-Salt Surface Reflection Beneath the Salt Pillar (from Loocke 1978) 
pre-salt surface beneath the dome whereas the seismic section shows an elevated pre-salt surface beneath the dome similar to that recorded on the actual seismic profile.

The primary salt withdrawal sink is identified as the position of maximum isochron values for the deeper reflection packages. Typically, the position of maximum isochron value is the same for several of the lowermost stratigraphic units. The position of the maximum isochron value is shown in on Figure 4. Proper identification of these positions requires that the seismic profile extends well beyond the center of the primary sink. However, a profile need not extend as far beyond the sink as does Figure 4.

Reflection quality is good from the pre-salt surface up to 0.5 seconds. An adequate number of seismic stratigraphic units are readily identified within this interval and may be correlated to either side of the dome. Shallow reflection quality is inadequate and should be supplemented by other types of data if the late history of the dome is to be accurately portrayed.

\section{PREPARING A RECONSTRUCTION}

A reconstruction of the growth history of an interior basin piercement salt dome is accomplished by adding, one at a time, each seismic unit on top of the last. In each step the top surface of the unit is presumed to be horizonta1. The isopach variation within the unit is accommodated by conformable deformation of the underlying sediments and salt. It is assumed that all deformation in the post-salt sediments is the result of deformation of the underlying salt. This assumption is very reasonable, because the pre-salt surface is planar and undeformed, whereas the sediments overlying the salt are highly deformed and exhibit significant variation in thickness across the area of investigation. Because of the horizontal and vertical dimensions involved and the limitation in precisely determining isopach thickness, the assumption of a flat surface is valid if sea floor relief is less than 200 feet over the study area. It is unlikely that the sea floor topography of a newly deposited unit exceeded this amount over the 1 imited area considered. 
The most accurate reconstruction of a dome's history is accomplished using a migrated depth section. Preparation of such a section requires accurate interval velocity data for the various seismic units. Experience has shown that normal move-out velocities are of insufficient accuracy for this purpose. Therefore, either velocity surveys or sonic logs at various sites within the area are needed for the required velocity information. To compound the problem, the interval velocities reflect both the lithology and depth of burial of a unit. From Figure 7 it is clear that the thickness and burial depths of most of the units vary widely across the area. Consequently, multiple surveys are required to permit an adequate representation. Where such data are unavailable, experience shows that isochron values may be used in the reconstruction with acceptable results. Migrated depth sections prepared with poor velocity data commonly are of poor quality and may make interpretation more difficult.

\section{AN EXAMPLE OF RECONSTRUCTION}

To illustrate the method, an example reconstruction of the Hainesville Dome, Wood County, Texas, is presented below. A line drawing of the migrated depth section used in the reconstruction is shown in Figure 7 . The initial salt surface is presumed to be a horizontal plane extending continuously across the present site of the dome. Upon this surface is placed the first seismic stratigraphic unit, the Smackover to Cotton Valley Lime sequence (Late Jurassic). This unit does not exhibit isopach variation, indicating that no deformation accompanied its deposition (Figure $8 \mathrm{a}$ ). The surface of the unit is interpolated across the present site of the dome. This interpreted value is maintained throughout successive stages in the reconstruction, except where erosion may have truncated it.

The second seismic unit exhibits systematic isopach variation, indicating contemporaneous deformation of the underlying salt and first sedimentary unit (Figure 8b). The unit corresponds to the Cotton Valley (Late Jurassic) and the Travis Peak (Early Cretaceous) formation. Thus, dome growth began during an episode of major deltaic sedimentation in the area. The resulting structure is a broad, low relief salt pillow that is 20 miles across with 1,800 feet of 


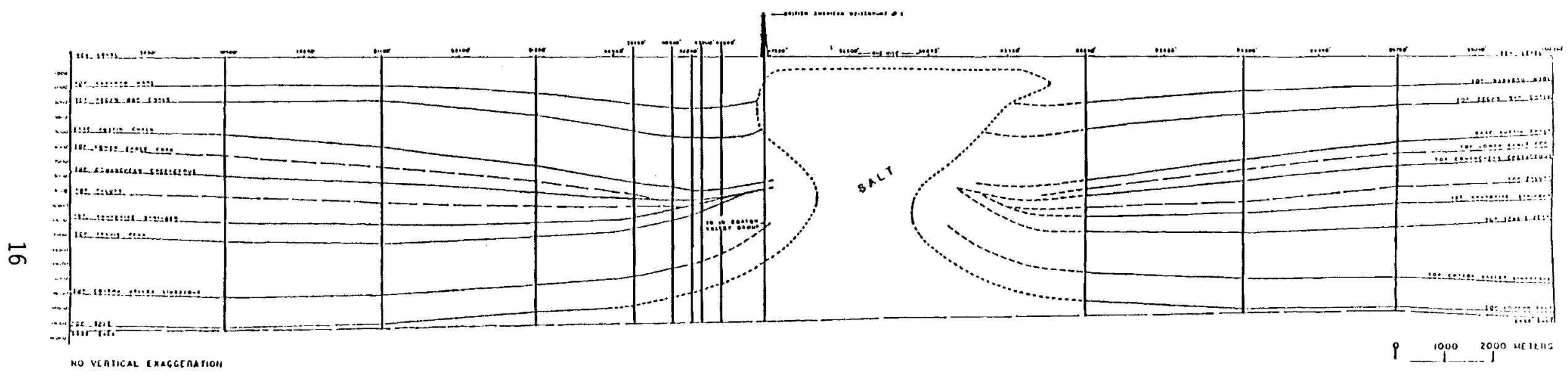

FIGURE 7. Depth Model Used in Reconstructing Growth History of the Hainesville Salt Dome, Wood County, Texas (from Loocke 1978) 


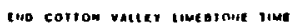

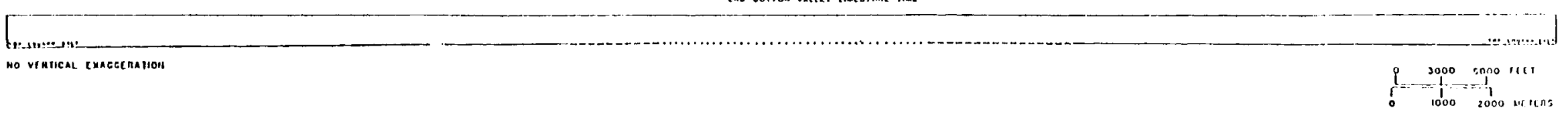

FIGURE 8a. Reconstruction - Datum Top Cotton Valley Limestone (from Loocke 1978)

P40 mavis mene verer

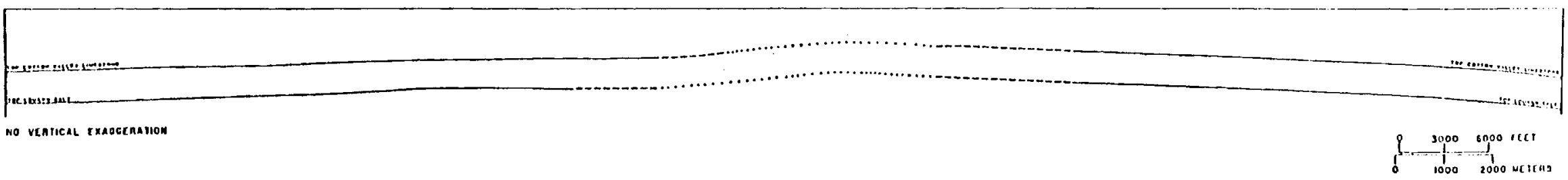

FIGURE 8b. Reconstruction - Datum Top Travis Peak (from Loocke 1978)

eno ringr Amuranire stmutarn twe

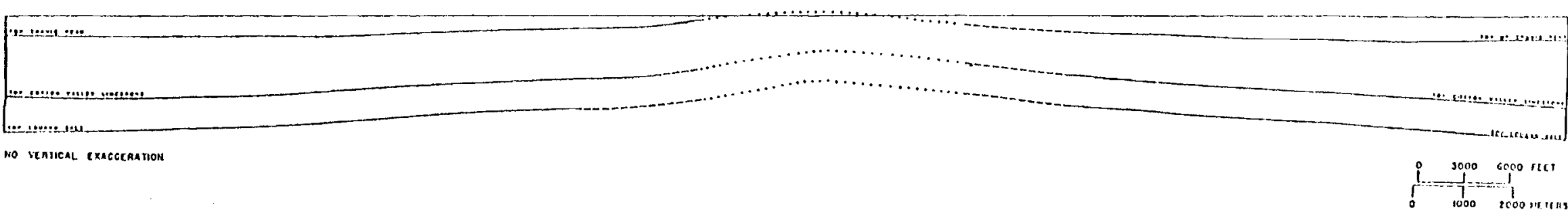

FIGURE 8C. Reconstruction - Datum First Anhydrite Stringer (from Loocke 1978) 
of structural relief. Again, the surface of the unit is interpolated across the no data area. More importantly, the shape of the deformed unit below is also interpolated. This interpolation is done in a conservative way; the curvature of the surface is always increased toward the dome crest, thus minimizing its elevation. The isopach thickness obtained in this manner is maintained in successive stages of the reconstruction.

Each succeeding unit is then added sequentially in the same manner as before. This is illustrated in Figure $8 \mathrm{c}$ and Figures $9 \mathrm{a}$ and $9 \mathrm{~b}$. Figure 10a represents the configuration of the structure in Eagle Ford time. At this time the feature was 13 miles wide, exhibited 12,000 feet of structural relief and potentially as much as 2,500 feet of topographic relief (assuming no erosion). If erosion of the crest kept pace with structural growth, the salt core of the structure would lie only a few feet below the surface at this time. This stage is critical in the growth of the structure. Shortly thereafter, salt breaks to the surface and begins extruding from the crest of the feature. This extrusion probably began in Austin Chalk time (Figure 10b). Extrusion of salt at the surface is accomplished by collapse of the original salt pillow. Incidently, there are salt structures in the interior basin that presently exhibit this stage of evolution. They are unsatisfactory storage sites, because future erosion would expose the salt core, allowing salt to escape. This loss of salt would allow collapse of the underlying structure accompanied by massive extrusion of salt and would result in the destruction of the storage site.

Figures $11 \mathrm{a}$ and 11b illustrate the development of "piercement" salt pillars. The salt extrudes from the eroded hole in the crest of the salt pillow, and the pillow collapses. The Upper Cretaceous sediments deposited at the time of extrusion abruptly onlap the extruding spine. The collapse of the original structure is reflected in the isopach character of these Upper Cretaceous units, which are thickest adjacent to the salt pillar. Thus, they demonstrate that salt was evacuated from the pillow to form the piercement pillar. 
eno enturer time

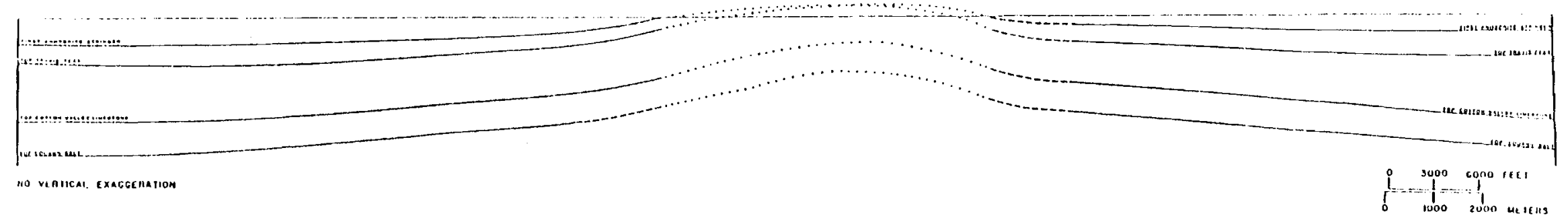

FIGURE 9a. Reconstruction - Datum Top Paluxy (from Loocke 1978)

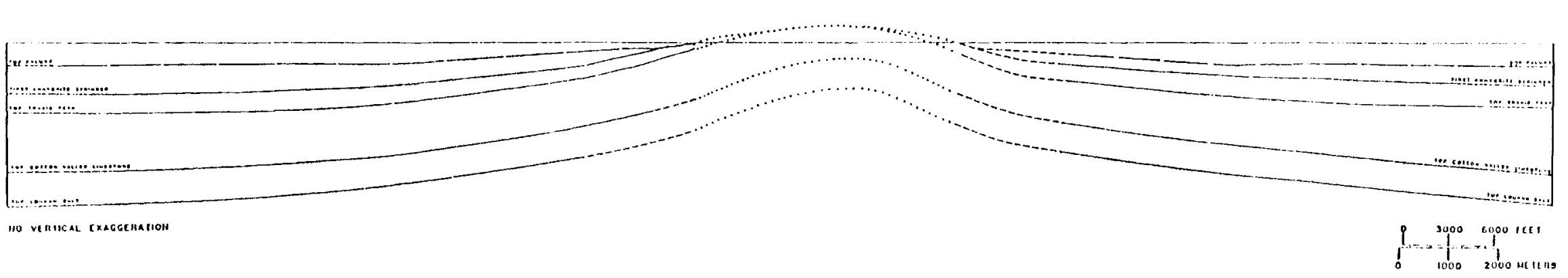

FIGURE 9b. Reconstruction - Datum Top Comanchean (from Loocke 1978) 
emo comen racer tono tiut

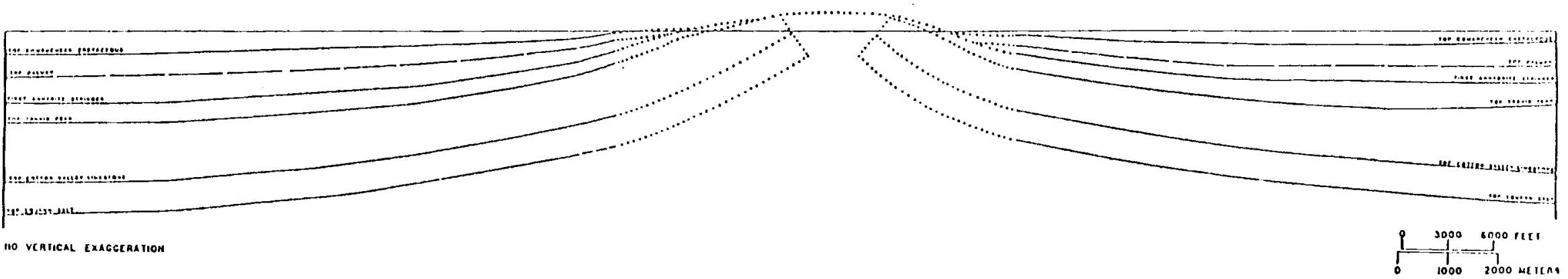

FIGURE 10a. Reconstruction - Datum Top Lower Eagle Ford (from Loocke 1978)

ge gintaHo AUS IM GHALK HUE

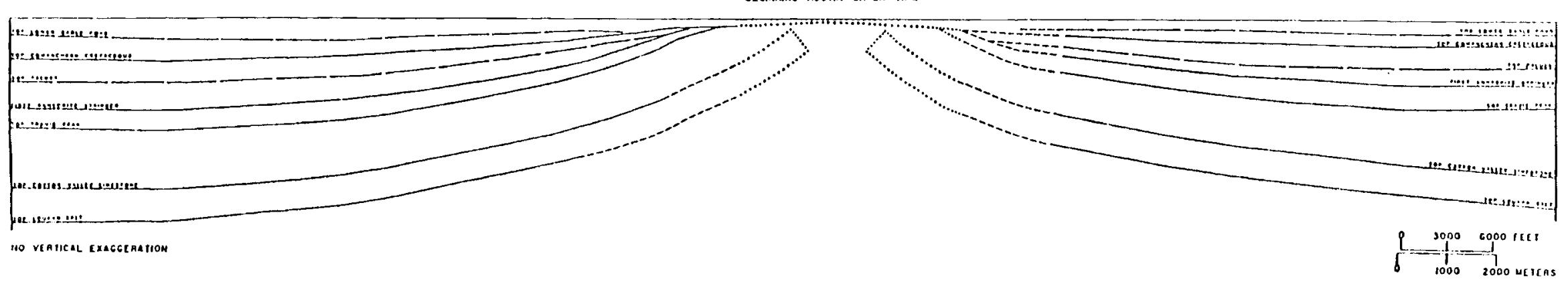

FIGURE 10b. Reconstruction - Datum Base Austin Chalk (from Loocke 1978) 


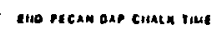

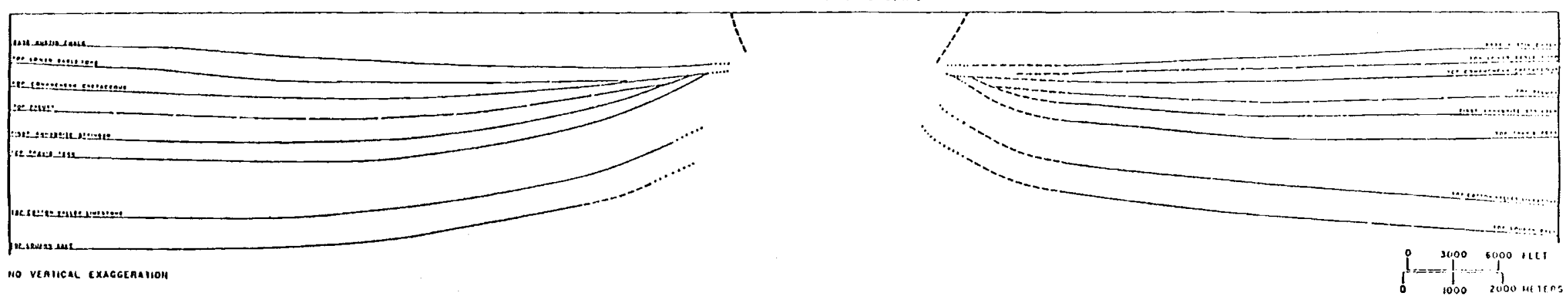

FIGURE 11a. Reconstruction - Datum Top Pecan Gap Chalk

(from Loocke 1978)

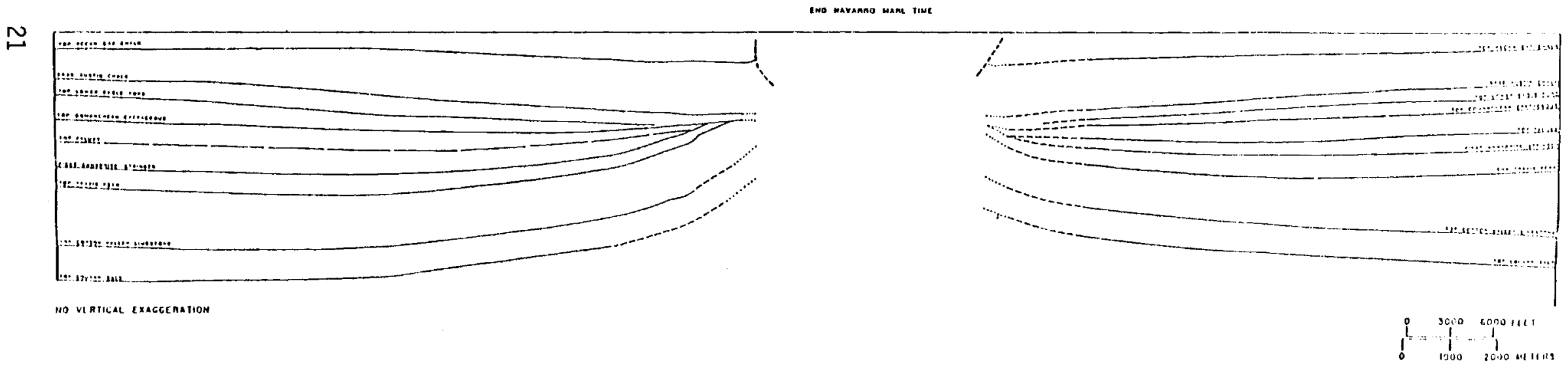

FIGURE 11b. Reconstruction - Datum Top Navarro Marl (from Loocke 1978) 
Volumetric calculations by Loocke (1978) show that 45 cubic miles of salt existed in the original salt pillow, but only 9 cubic miles are now present in the salt pillar. The remaining 36 cubic miles were dissolved and eroded away during the formation of the "piercement" pillar during the Late Cretaceous.

The seismic data quality is insufficient to accurately define the time at which dome growth ceased. But, abundant shallow well control in the area permits the mapping of latest Cretaceous strata across the dome, establishing that activity ceased nearly 60 million years ago.

A more detailed account of the reconstruction methods and the growth history of the Hainesville Dome is presented by Loocke (1978).

GEOLOGIC HAZARDS TO A SALT DOME STORAGE SITE

A principal concern for long-term, safe storage of nuclear wastes in salt domes arises from the fear that salt dome growth may lift the storage facility to a shallow depth or to the surface of the earth where the facility could be breached by surface processes. But the maximum uplift rates experienced by piercement domes during their most unstable period, which is during extrusion, are only 2,000 feet per million years. Such low uplift rates would permit the design of a safe storage site in a growing dome, despite the fact that to do so would not be the best alternative. The uplift rates attributable to stable, mature domes are negligible, even for significant geologic time periods. These rates are on the order of 20 feet per million years or less. Because domes in this evolutionary stage cannot be reactivated, they may be considered as potential sites for nuclear waste storage. Breaching of a salt dome site by faulting or ground rupture during earthquakes is judged to be unlikely. Salt plasticity is such that rupture is unlikely, and any fractures created within a salt mass at the depths anticipated for a storage facility would quickly close and heal as a result of salt flowage.

A second major concern, not addressed here, is that ground water will dissolve the salt, directly exposing the storage facility to flowing ground water. 
The rate of uplift of a storage facility located within a salt dome is a critical factor in erosional breaching of a storage facility. Geologic evidence suggests that sub-aerial erosion generally keeps pace with dome growth. Consequently, if dome growth occurs, the total amount of uplift during the prescribed storage interval must still leave the storage site a safe distance below the ground surface. This criterion for safe storage can be stated explicitly as follows: uplift rate of the facility times storage time must be less than or equal to the original depth of the site minus a minimum safe depth of burial. As an example, if the storage site is initially 1,500 feet below the surface, the storage interval is 500,000 years and the minimum safe burial depth is 500 feet below the surface, then the maximum permissible uplift rate equals 2,000 feet per million years. Of course, uplift rates significantly smaller than this amount would be desirable. Consequently, a critical geologic variable in assessing the structural suitability of a potential salt dome storage site is uplift rate.

Several workers have estimated salt dome uplift rates using structural relief data obtained from sediments enveloping the dome. This method, discussed below, underestimates the maximum uplift rates, because it does not account for the extrusion of salt from the core of the structure. Extrusion rate can also be estimated, provided adequate subsurface and seismic data are available.

The graph of structural relief versus time (Figure 12) shows that dome growth at Hainesville began slowly, accelerated to a period of very rapid growth and then decelerated to a negligibly slow rate. Maximum rate of structural uplift equaled nearly 800 feet per million years during the mid-Cretaceous, just prior to exposure of the salt core at the surface. Minimum growth rates occurred during the past 40 million years, during which time growth probably ceased. Cessation of growth cannot be proved because no strata younger than 40 million years in age cap the dome. Instead, the total uplift of the youngest strata present on the dome is assumed to have occurred at the beginning of the time period, and the rate of uplift has probably decelerated since then. Because no salt remains in the original salt pillow to feed future growth, no acceleration or rejuvenation of dome growth is anticipated. 


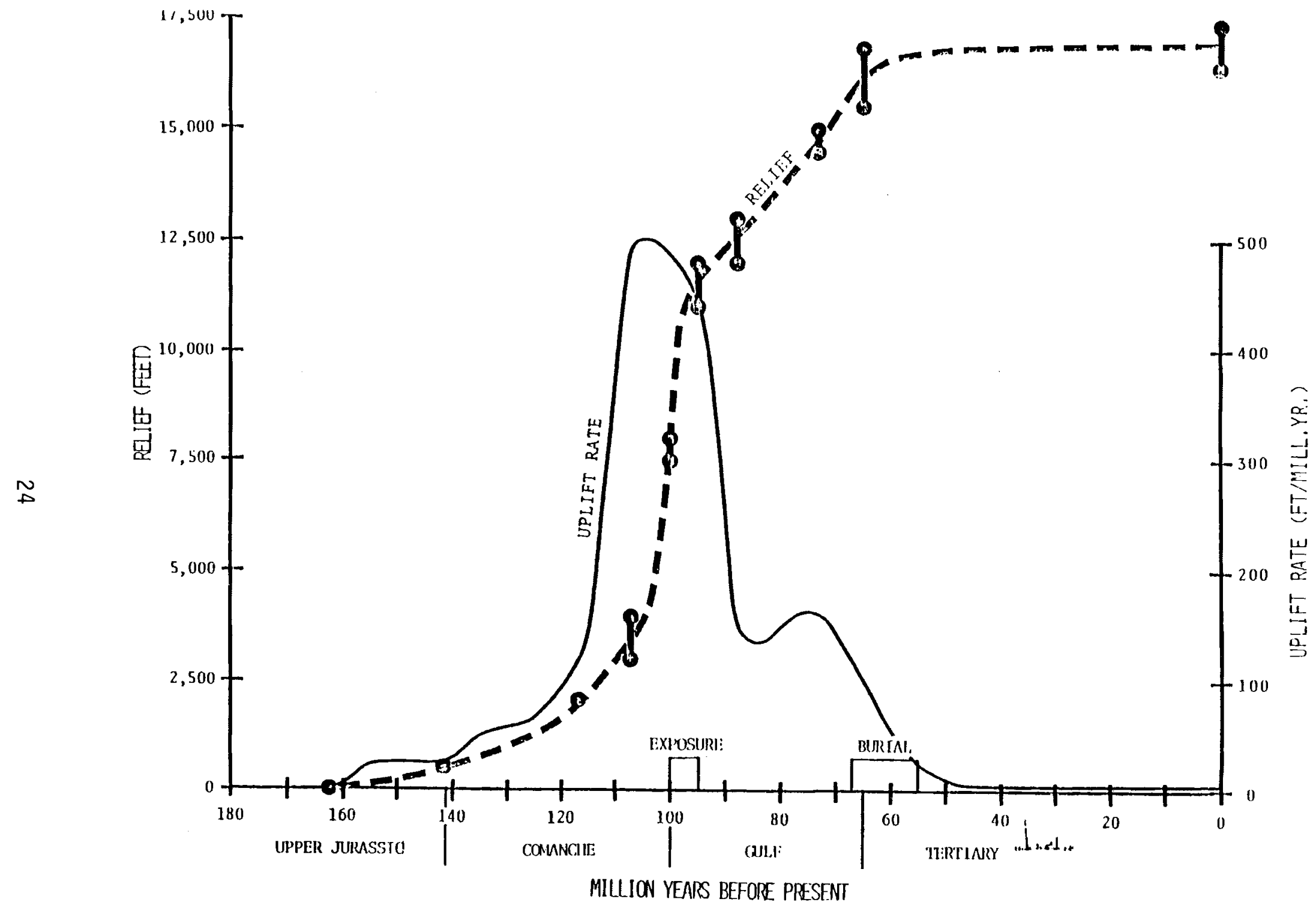

FIGURE 12. Structural Relief - Hainesville Salt Dome 
The above described method adequately measures uplift rate, provided that the salt core of the dome is covered by other rocks. During extrusion no rocks cover the crest of a dome, and salt rapidly escapes through the hole in the cover of enveloping sedimentary rocks. A facility emplaced within the salt core would experience this rapid uplift, not the much slower uplift rate of the surrounding sediments. The upward velocity of the salt escaping from the original salt pillow may be estimated reliably using the method outlined below, provided adequate subsurface and seismic data exist.

The escape velocity of the salt cannot be measured directly. Rather, it is calculated from a knowledge of the volume of salt loss during a known time interval divided by the cross-sectional area of the hole through which the salt escaped.

The volume of salt loss during a geologic time interval is estimated from the amount of collapse of the underlying salt pillow during that interval. The collapse volume is reflected directly in the isopach of the sedimentary unit deposited during the time interval in question. The minimum thickness of the unit which occurs at the outer edge of the rim syncline is assumed to reflect local subsidence of basement during the time interval. This assumption is reasonable, provided that the locality has not suffered uplift because of salt flowage. It is presumed that this thickness would have been deposited over the entire area if salt had not been withdrawn. The volume of salt withdrawal is assumed to equal the excess sedimentary volume in the rim syncline area over that calculated from the minimum thickness observed. The volume of salt loss is taken to be equal to the salt withdrawn minus the salt remaining in the salt pillar. This information is plotted on Figure 12 versus time before present and is labeled "loss rate."

The area of salt exposed at the surface during any geologic time interval is also estimated from isopachs of stratigraphic intervals deposited during extrusion. It is presumed that the zero depositional edge marks the position of the salt-sediment contact. The area within this zero edge is assumed to be the area through which salt is lost. The exposed area, plotted versus time before present, is shown on Figure 13. The vertical salt velocity or uplift 


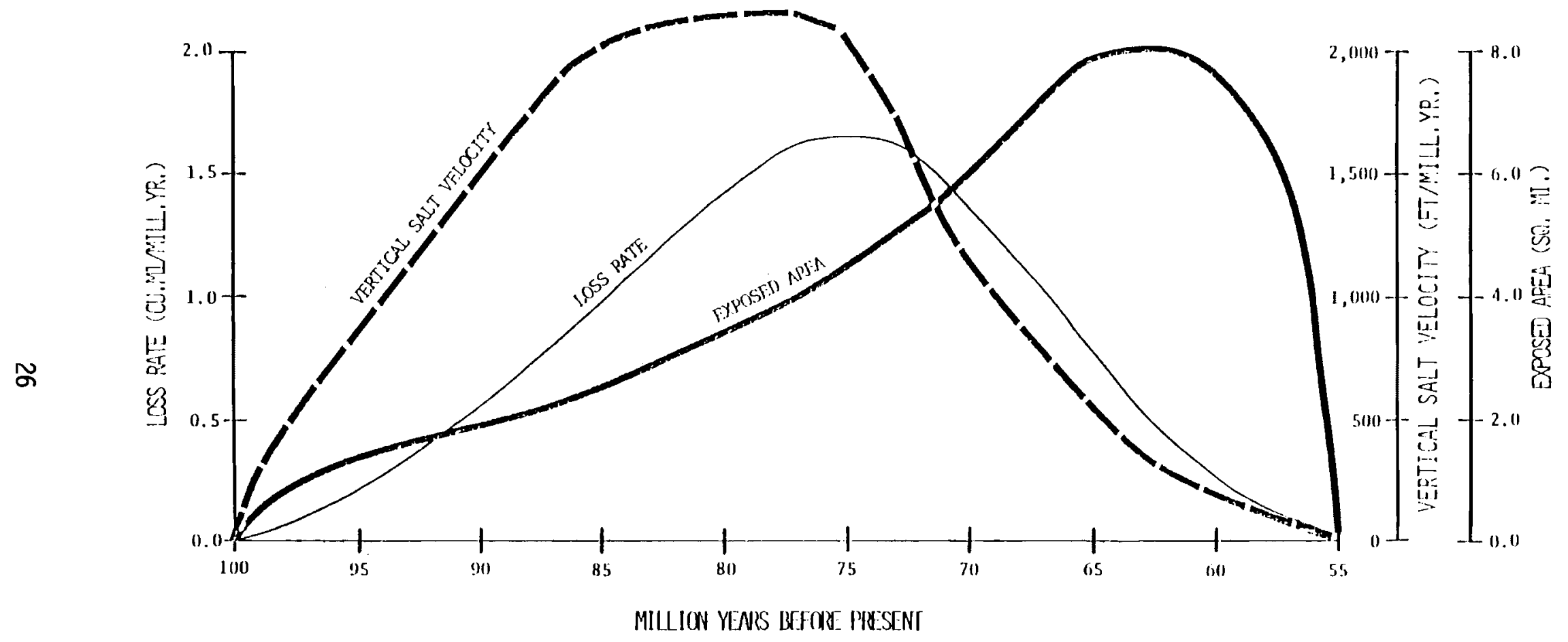

FIGURE 13. Salt Loss - Hainesville Salt Dome 
rate at the ground surface equals the quotient of total loss rate divided by the exposed area. This quotient is shown on Figure 13 as vertical salt velocity and is plotted versus time before present.

Figure 13 shows that the maximum vertical rise rate of the salt during extrusion equaled 2,000 feet per million years and occurred during a 10 million year period that ended 75 millions years before the present. Extrusive uplift ceased 55 million years before the present, by which time most of the salt had been evacuated from the original salt pillow. The residual salt pillar was then buried beneath pro-delta muds of the advancing Wilcox delta system. Although minor extrusion from the collapsed pillow has occurred during the last $55 \mathrm{million}$ years, no measurable salt volume has been lost. The extruded salt simply added slightly to the height of the salt pillar.

Interestingly, even the maximum extrusion rate of 2,000 feet per million years at Hainesville dome would permit the design of an acceptable storage facility in a similar interior basin salt dome. Maximum rates at Minden dome, Louisiana, have been estimated at 722 feet per million years. The extrusion rates exhibited by these two domes may well be the largest in East Texas and North Louisiana, because the initial salt pillows on these domes contained the largest volume of salt for any dome in their respective basins. If this theory is correct, then uplift is unlikely to be hazardous to a salt dome storage facility located at 1,500 feet below the surface or deeper, regardless of the choice of the dome for the storage site.

A more prudent criterion would be to select a mature dome that has passed through the extrusion phase. Uplift rates following post-extrusion burial are less than 20 feet per million years. Such a rate is totally negligible. From a structural viewpoint, a mature interior basin salt dome could be considered as a potential site for a waste storage facility. 


\section{RECOMMENDED INVESTIGATION PROGRAM}

Identification of stable, mature salt domes can be accomplished most satisfactorily through a reconstruction of the growth history of the domes using high quality CDP seismic reflection profiles across candidate domes. Shallow reflection data, used to establish the geologic age at which a dome reaches maturity and dome growth ceases, is inadequate on CDP profiles. The CDP profiles must be supplemented by high-frequency, shallow-focus seismic profiles and by shallow borehole logs. If candidate domes are restricted to those whose caprocks occur at least 500 feet below the surface, a large amount of borehole data will not be needed; the exact dome configuration is less important for domes with significant burial depths. Much of the needed information can be derived from the high-frequency, shallow-focus seismic data.

\section{CDP PROFILE NEEDED}

Suitable CDP seismic data have been collected in the vicinity of many of the interior basin domes, and many are available from either geophysical exploration companies or through brokers. These data may be inspected prior to purchase to insure suitability. The cost is far less than specially acquired data (about $\$ 500$ per mile versus $\$ 3,000$ per mile). The author recommends that one of the preliminary screening criteria be the availability of one or more adequate seismic profiles across a candidate structure. If no data are available across any of the candidate domes, then the author recommends that several of the most prospective candidates be selected for seismic profiling. The location of the lines, the field methods employed and the processing techniques used are site specific and cannot be properly addressed here. Concurrent processing with field data acquisition, however, is essential to insure that usable data are being collected. 
SHALLOW SEISMIC AND BOREHOLE CONTROL

More detailed shallow investigations should await interpretation of the CDP seismic data. Provided that a dome is found to be in a mature, stable configuration, a detailed, high-frequency, shallow-focus seismic investigation should be designed to determine the geometry of shallow beds across the dome. Once the geometry is adequately known, selected shallow boreholes ought to be drilled and logged to confirm the geometric interpretation and to establish the geologic age when dome growth terminated. This drilling program should also be designed (with the aid of the shallow seismic data) to supply needed information on the ground water regime. Provided that the shallow seismic data are of good quality and that the dome exhibits a simple shallow geometry, only a few boreholes need be drilled to supply the requisite information. Again, the number will be site specific. Regardless, each test hole should be logged with an electric $\log$ and at least two porosity devices, probably a density and compensated neutron log combination. Selected wells should be equipped for pump tests and provisions for the acquisition of uncontaminated ground water samples need to be made. 


\section{REFERENCES}

Fisher, W. F. 1973. "Deltaic Sedimentation, Salt Mobilization and Growth Faulting in the Gulf Basin." Am. Assoc. Petroleum Geologists Bull., $57: 779$.

Heard, H. C. 1976. "Comparison of the Flow Properties of Rocks at Crustal Conditions." Philosophical Trans. Royal Soc. London, Ser A, 238:173-186.

Kehle, R. 0. 1971. "Origin of the Gulf of Mexico." Unpub. manuscript, Univ. of Texas at Austin, Geol. Lib., call no. q557 K260, unpaged.

Loocke, J. E. 1978. "Growth History of the Hainesville Salt Dome, Wood County, Texas." Unpub. M.A. Thesis, Univ. of Texas at Austin, 95 p.

Sannemann, D. 1968. "Salt-Stock Families in Northwestern Germany," in Diapirism and Diapirs, eds. Braunstein, J., and G. 0. O'Brien. Am. Assoc. Petroleum Geologists Mem. 8:261-70.

Trusheim, F. 1960. "Mechanism of Salt Migration in Northern Germany." Am. Assoc. Petroleum Geologists Bul1., 44(9):1519-1540. 


\section{DISTRIBUTION}

No. of

Copies

\section{OFFSITE}

2 Argonne National Laboratory Reference Library 9800 S. Cass Ave. Argonne, IL 60439

Battelle Memorial Institute Office of Nuclear Waste Isolation 505 King Ave.

Columbus, $\mathrm{OH} 43201$

Attn: Bever ly Rawles

2 Brookhaven National Laboratory Reference Section Information Division Upton, Long Is 1 and, NY 11973

27 DOE Technical Information Center

John Bird

Geology Department

Corne11 University

Ithaca, NY 14853

John Bredehoeft

U.S. Geological Survey

Reston, VA 22092

Robert Budnitz

U.S. Nuclear Regulatory

Commission

Washington DC 29545

Colin Bull

Office of the Dean

College of Math and Physical

Sciences

Ohio State University

164 W. 17th Ave.

Columbus, $\mathrm{OH} 43201$
No. of

Copies

Harry C. Burkholder

Office of Nuclear Waste

Isolation

Battelle Memorial Institute

505 King Ave.

Columbus, $\mathrm{OH} 43201$

Jim Campbe 11

T39

Division 5413

Sandia Labs

Albuquerque, NM 87185

20 Wayne A. Carbiener

Office of Nuclear Waste Isolation

Battelle Memorial Institute

$505 \mathrm{King}$ Avenue

Columbus, $\mathrm{OH} 43201$

A. A. Churm

DOE Patent Division

9800 So. Cass Ave.

Argonne, IL 60439

H. Clyde Claiborne

Oak Ridge National Laboratory

P.0. Box X, Building 3017

Oak Ridge, TN 37830

James $\mathrm{Clark}$

c/o Eugene Vetter

Route 2, Box 70

Shawano, WI 54166

Neville G. W. Cook

Dept. of Materials Science and Mineral Engineering

Hearst Mining Building

University of California

Berkeley

Berkeley, CA 94720 
No. of

Copies

Carl R. Cooley

DOE Office of Waste Management

Washington DC 20545

Howard A. Coombs

Department of Geological

Sciences

University of Washington

Seattle, WA 98194

James W. Crosby III

1467 Alpowa

Moscow, ID 83843

Bruce Crowe

Geological Research Group, G-6

Los Alamos Scientific

Laboratory

P.0. Box 1663

Los Alamos, NM 87545

Jared Davis

27 Nuclear Regulatory Commission

Washington DC 20555

Stanley N. Dav is

6540 W. Box Canyon Drive

Tuc son, AZ 85705

G. L. DeBuchananne

U.S. Geological Survey

Reston, VA 22092

Terry Don ich

Lawrence Livermore Laboratory

P.0. Box 808

Livermore, CA 94550

James Duguid

Office of Nuclear Waste

Isolation

Battelle Memorial Institute

Columbus, $\mathrm{OH} 43201$

Don Easterbrook

Western Washington University

Bellingham, WA 98225
No. of

Copies

Dan Egan

U.S. Environmental Protection Agency

Washington DC 20545

Environmental Protection Agency

Office of Radiation Programs

Technical Assessment Division Aw559

Washington DC 20460

J. G. Feinste in

NUS Corporation

4 Research Place

Rockville, MD 20850

Graham E. Fogg

Bureau of Economic Geology

The University of Texas

Austin

University Station, Box $X$

Austin, TX 78712

Robert M. Garrells

Dept. of Geologic Sciences

Northwestern University

Evanston, IL 60201

Raymond D. Gastil

Freedom House

20 W. 40th St.

New York, NY 10018

Earnest Gloyna

National Academy of Sciences

University of Texas

Aust in, TX 78712

George Griswold

Tecolote Corporation

531 Wagon Train Drive SE

Albuquerque, NM 87123

Charles R. Had lock

Arthur D. Little, Inc.

Acorn Park

Cambridge, MA 02140 
No. of

Copies

Colin A. Heath

DOE Division of Waste Management

Washington DC 20545

William M. Hewitt

Office of Nuclear Waste Isolation

Battelle Memorial Institute

505 King Ave.

Columbus, $\mathrm{OH} 43201$

John M. Hills

818 Kerbey Ave.

El Paso, TX 79902

Peter L. Hofmann

Office of Nuclear Waste Isolation

Battelle Memorial Institute $505 \mathrm{King}$ Avenue

Columbus, $\mathrm{OH} 43201$

John T. Holloway

Committee on Radioactive Waste Management $\mathrm{JH}-826$

National Academy of Sciences

2101 Constitution Ave. NW

Washington DC 20418

Vojin Joksimovic

General Atomic Company

P.0. Box 81608

San Diego, CA 92138

Louis S. Karably

Law Engineering

2749 Delk Road SE

Marietta, GA 30067

R. F. Kaufman

Converse Ward Davis Dixon

4055 Spencer, Suite 120

Las Vegas, NV 89109
No. of

Copies

10 Ralph Kehle

7800 Shoul Creek Blvd.

Suite 270S

Aust in, TX 78757

Muzaffer Kehnemuyi

Office of Nuclear Waste Isolation

Battelle Memorial Institute 505 King Ave.

Columbus, $\mathrm{OH} 43201$

John F. Kircher

Office of Nuclear Waste Isolation

Battelle Memorial Institute 505 King Ave.

Columbus, $\mathrm{OH} 43201$

Charles Koplick

The Analytic Sciences Corp. 6 Jacob Way

Reading, MA 01867

Charles W. Kreitler

Texas Bureau of Economic Geology

University Station, Box $X$

Austin, TX 78712

George K. Kukla

Lamont-Doherty Geological Observatory

Palisades, NY 10964

Donald H. Kupfer

Department of Geology

Louisianna State University

Baton Rouge, LA 70803

Ronald B. Lantz

INTERA Environmental Consultants, Inc.

11511 Katy Freeway

Houston, TX 77079 
No. of

Copies

2 Lawrence Berkeley Laboratory

Reference Library

University of California

Berkeley, CA 94720

2 Lawrence Livermore Laboratory

Reference Library

P.0. Box 808

Livermore, CA 94550

Darrelle I. Leap

USGS, WRD, MS416

Box 25046

Denver Federa 1 Center

Denver, CO 80225

Richard Lincoln

Sandia Laboratories

N.N.W.S.I.

NTS Technical Overview

Division 4538

Albuquerque, NM 87185

Stan ley $E$. Logan

Nuc lear Waste Management Program

Los Alamos Technical Associates, Inc.

P.0. Box 410

Los Alamos, NM 87554

Ear 1 M. Lovejoy

4400 Fairview Road

Reno, NV 89511

S. J. Mara

SRI Internationa 1

333 Ravenswood Avenue

Men lo Park, CA 94025

Peter D. Mattison

Arthur D. Little, Inc.

Acorn Park

Cambridge, MA 02140
No. of

Copies

W. C. McClain

Oak Ridge National Laboratory

P.0. Box $X$

Oak Ridge, TN 37830

John T. McGinn is

Office of Nuclear Waste Isolation

Battelle Memorial Institute

505 King Ave.

Columbus, $\mathrm{OH} 43201$

She ldon Meyers

DOE Office of Nuclear Waste

Management

Washington DC 20545

Peter A. Mote

Bechte 1, Inc.

P.0. Box 3965

San Francisco, CA 94105

2 Barry Naft

NUS Corporation

4 Research Place

Rockville, MD 20805

J. 0. Neff

Department of Energy

Columbus Program Office

505 King Ave.

Columbus, $\mathrm{OH} 43201$

Robert H. Neil

State of New Mexico

Environmental Evaluation Group

P.0. Box 968

Santa Fe, NM 87503 
No. of

Copies

2 Neil Norman

Environmental Sciences Dept.

Bechtel National, Inc.

P.0. Box 3965

San Francisco, CA 94105

2 Los Alamos Scientific Laboratory

Reference Library

P.0. Box 1663

Los Alamos, NM 87544

2 Oak Ridge National Laboratory

Central Research Library

Document Reference Section

Oak Ridge, TN 37830

Suresh B. Pahwar

INTERA Environmental Consultants, Inc.

11511 Katy Freeway, Suite 630

Houston, TX 77079

Frank L. Parker

Dept. of Environmental

Engineering

Vanderbilt University

Nashville, TN 37235

David E. Pauls

Law Engineering and Testing Co.

2749 Delk Road SE

Marietta, GA 30067

James Pearson

INTERA Environmental

Consultants, Inc.

11511 Katy Freeway, Suite 630

Houston, TX 77079

George F. Pinder

Dept. of Civil Engineering

Stanford University

Stanford, CA 94305
No. of

Copies

Larry Ramspott

Technical Program Officer

Lawrence Livermore Laboratory

P.0. Box 808

Livermore, CA 94550

Linda Robinson

NUS Corporation

4 Research Place

Rockville, MD 20850

Savannah River Laboratory

Reference Library

Aiken, SC 29801

Maurice L. Schwartz

Department of Geology

Western Washington University

Bellingham, WA 98225

Genevieve Segol

Bechtel, Inc.

P.0. Box 3965

San Francisco, CA 94105

Herb Shaw

U.S. Geological Survey

Mail Stop 18

345 Middlefield Road

Men lo Park, CA 94025

Dillard B. Shipler

Office of Nuclear Waste Isolation

Battelle Memorial Institute

505 King Ave.

Columbus, $\mathrm{OH} 43201$

James N. Siltanen

General Atomic Company

P.0. Box 81608

San Diego, CA 92138

George M. Slaughter

Law Engineering and Testing Co.

2749 Delk Road SE

Marietta, GA 30067 
No. of

Copies

Barry J. Smernoff

Hudson Institute

Quaker Ridge Road

Croton-On-Hudson, NY 10520

Terry Ste inborn

Lawrence Livermore Laboratories

P.0. Box 808

Livermore, CA 94550

Howard P. Stephens

Sandia Laboratories

N.N.W.S.I.

Division 4538

Albuquerque, NM 87185

James I. Stevens

Arthur D. Little, Inc.

Acorn Park

Cambridge, MA 02140

David B. Stewart

U.S. Geological Survey National Center 959

Reston, VA 22092

Robert L. Thoms

Institute for Environmental

Studies

Louisianna State University

Baton Rouge, LA 70803

Newe 11 Trask

U.S. Department of the Interior Geological Survey

Mail Stop 929

Reston, VA 22092

W. S. Twenhofel

USGS

Mail Stop 954

Denver, CO 80225

Maurice D. Veatch

6834 - 51st Ave. NE

Seattle, WA 98115
No. of

Copies

W. Weart

Division 1140

Sandia Laboratories

Albuquerque, NM 87115

Lawrence Wight

TERA

2150 Shaltuck Ave.

Berkeley, CA 94704

Charlie Wilson

Earth Sciences Division

Lawrence Livermore Laboratory

Building 90

Berkeley, CA 94720

Paul Witherspoon

Earth Sciences Division

Lawrence Livermore Laboratory

Building 90

Berkeley, CA 94720

FOREIGN

D'Allessandro Avogadro

Commission of European

Communities

Joint Rersearch Centre

I-21020 Ispra (Varese)

ITALY

K. H. Hubenthal

Bundesministerium fur Forschung und Technologie

Stressemannstrasse 2

Postfach 200706

D-5300 Bonn

F.R. Of GERMANY

Le if Carlsson

Geological Survey of Sweden

Bredgrand 4

S-753 20 UPPSALA

$018 / 155640$

SWEDEN 
No. of

Copies

Center for Atomic Energy Documentation (ZAED)

ATTN: Dr. Bell

Postfach 3640

D-7500 Kar lsruhe

$F . R$. of GERMANY

Ken Dornuth

Atomic Energy Canada Ltd. Whiteshe 11 Nuclear Research Establishment

Pinawa, Manitoba ROE 1 LO

CANADA

F. Gera

Nuclear Energy Agency/OECD

38 boulevard Suchet

F-75016 Paris

FRANCE

2 INIS Clearinghouse

International Atomic Energy Agency

P.0. Box 590

A-1011, Vienna

AUSTRIA

Klaus Kuhn

Institut fur Tiefagerung

Wissenschaftliche Abteilung

Berliner Strasse 2

D-3392 Clausthal - Zellerfeld

$F . R$. of GERMANY

Hans W. Levi

Hahn-Meitner-Institut fur Kernforschung

Glienicker Strasse 100

D-1000 Berlin 39

$F . R$. of GERMANY

Library

Studsvik Energiteknik $A B$

S-611 01 Nykoping

SWEDEN
No. of

Copies

Takehico Ngamatsu

Geologist

Chief Representative Vancouver Office

Mitsubishi Metal Corporation

78 Granville Square

200 Granville Street

Vancouver, BC V6C 1S4

CANADA

Franz Peter Oester le

Physikalisch-Chemische Bundesanstalt

Bundesallee 100

D-3300 Braunschweig

F.R. of GERMANY

F. P. Sargent

Atomic Energy of Canada, Ltd.

Whiteshell Nuclear Research

Establ ishment

Pinawa, Manitoba ROE 1 LO

CANADA

Noritaka Sato

Chief Geologist, Domestic Exploration \& Nuclear Resources

Mitsubishi Metal Corporation

1-5-2 Ohte-Machi

Chiyoda-Ku, tokyo

JAPAN

Egbert Schapermeier

Battelle-Inst itute e.V.

Am Romerhof 35

D-6000 Frankfurt am Main 90

$F$. R. of GERMANY

Tjalle Vandergraff

Atomic Energy of Canada Limited

Whiteshell Nuclear Research

Establishment

Pinawa, Manitoba ROE $1 \mathrm{LO}$

CANADA 
No. of

Copies

ONSITE

5 Department of Energy

0. J. Elgert

H. E. Ransom

J. J. Schre iber

D. J. Squires

F. R. Standerfer

7 Rockwell Hanford Operations

R. L. Biggerstaff

D. J. Brown

R. A. Deju

G. S. Hunt

R. E. Isaacson

G. L. Jones

Rockwell Document Control

44 Pacific Northwest Laboratories

E. M. Arnold

G. L. Benson
No. of

Copies

R. A. Craig

W. J. Deutsch

F. H. Dove (10)

M. A. Harwe 11

M. R. Kreiter

J. W. Lindberg

R. F. McCallum

K. S. Murthy

G. M. Petrie

A. M. Platt

L. S. Prater

J. F. Relyea

D. J. Silviera

J. A. Stottlemyre

R. W. Wallace

J. T. Zellmer

Technical Information Library (5)

Publishing Coordination $\mathrm{SH}(2)$

Water and Land Resources

Department Library (10) 